\title{
The Masquerade Game: marine mimicry adaptation between egg-cowries and octocorals
}

Juan A Sánchez, Angela P Fuentes-Pardo, Íde Ní Almhain, Néstor E Ardila-Espitia, Jaime Cantera-Kintz, Manu Forero-Shelton

Background. Background matching, as a camouflage strategy, is one of the most outstanding examples of adaptation, where little error or mismatch means high vulnerability to predation. It is assumed that the interplay of natural selection and adaptation are the main evolutionary forces shaping the great diversity of phenotypes observed in mimicry, however there may be other significant processes that intervene in the development of mimicry such as phenotypic plasticity. Based on observations of background mismatching during reproduction events of egg-cowries, sea snails of the family Ovulidae that mimic the octocoral where they inhabit, we wondered if they match the host species diversity. Using observations in the field and molecular systematics, we set out to establish whether the different egg-cowrie color/shape polymorphisms correspond to distinct lineages restricted to specific octocoral species. Methods. Collection and observations of egg-cowries and their octocoral hosts were done using SCUBA diving between 2009-2012 at two localities in the Tropical Eastern Pacific (TEP), Malpelo Island and Cabo Corrientes (Colombia). Detailed host preference observations were done bi-annually at Malpelo Island. We analyzed the DNA sequence of the mitochondrial genes COI and 16S rDNA, extensively used in phylogenetic and DNA barcoding studies, to assess the evolutionary relationship among different egg-cowrie colorations and morphologies. Results. No genetic divergence among egg-cowries associated to different species of the same octocoral genus was observed based on the two mitochondrial genes analyzed. For instance, all egg-cowrie individuals from the two sampled localities observed on 8 different Pacifigorgia-Eugorgia species showed negligible mitochondrial divergence yet large morphologic divergence, which suggests that morphologies belonging to at least two sea snail species, Simnia avena (=S. aequalis) and Simnialena rufa, can cross-fertilize. Discussion. Our study system comprised backgroundmatching mimicry, of the masquerade type, between egg-cowries (Simnia/Simnialena) and octocorals (Pacifigorgia/Eugorgia/Leptogorgia). We observed mimicry mismatches related to fitness trade-offs, such as reproductive aggregations vs. vulnerability against predators. Despite the general assumption that coevolution of mimicry involves speciation, eggcowries with different hosts and colorations comprise the same lineages. Consequently, we 
infer that there would be significant tradeoffs between mimicry and the pursuit of reproductive aggregations in egg-cowries. The findings of this study not only contribute to the understanding of the evolution of mimicry in egg-cowries, a poorly studied group of marine gastropods, but also to the development of a new biologically meaningful board game that could be implemented as a learning tool. 
1 The Masquerade Game: marine mimicry adaptation between egg-cowries and octocorals

2

3

4

5

6

7

8

9

10

11

${ }^{2}$ Departamento de Biología-Facultad de Ciencias Naturales y Exactas, Grupo de Investigación en

14 Ecología de Estuarios y Manglares (ECOMANGLARES), Universidad del Valle, Cali,

15 Colombia.

$16{ }^{3}$ Department of Biology-Faculty of Sciences, Dalhousie University, Halifax, Canada.

${ }^{4}$ Departamento de Física, Universidad de los Andes, Bogotá, Colombia

$21 *$ Corresponding author, Juan A. Sánchez, Departamento de Ciencias Biológicas-Facultad de 22 Ciencias, Laboratorio de Biología Molecular Marina-BIOMMAR, Universidad de los Andes, 23 Bogotá, Colombia email: juansanc@uniandes.edu.co 


\section{Abstract}

26 Background. Background matching, as a camouflage strategy, is one of the most outstanding

27 examples of adaptation, where little error or mismatch means high vulnerability to predation. It is assumed that the interplay of natural selection and adaptation are the main evolutionary forces shaping the great diversity of phenotypes observed in mimicry, however there may be other significant processes that intervene in the development of mimicry such as phenotypic plasticity. Based on observations of background mismatching during reproduction events of egg-cowries, sea snails of the family Ovulidae that mimic the octocoral where they inhabit, we wondered if they match the host species diversity. Using observations in the field and molecular systematics, we set out to establish whether the different egg-cowrie color/shape polymorphisms correspond to distinct lineages restricted to specific octocoral species.

Methods. Collection and observations of egg-cowries and their octocoral hosts were done using SCUBA diving between 2009-2012 at two localities in the Tropical Eastern Pacific (TEP), Malpelo Island and Cabo Corrientes (Colombia). Detailed host preference observations were done bi-annually at Malpelo Island. We analyzed the DNA sequence of the mitochondrial genes COI and $16 \mathrm{~S} r D N A$, extensively used in phylogenetic and DNA barcoding studies, to assess the evolutionary relationship among different egg-cowrie colorations and morphologies.

42 Results. No genetic divergence among egg-cowries associated to different species of the same octocoral genus was observed based on the two mitochondrial genes analyzed. For instance, all egg-cowrie individuals from the two sampled localities observed on 8 different PacifigorgiaEugorgia species showed negligible mitochondrial divergence yet large morphologic divergence, 
46 which suggests that morphologies belonging to at least two sea snail species, Simnia avena $(=S$.

47 aequalis) and Simnialena rufa, can cross-fertilize.

48 Discussion. Our study system comprised background-matching mimicry, of the masquerade

49 type, between egg-cowries (Simnia/Simnialena) and octocorals

50 (Pacifigorgia/Eugorgia/Leptogorgia). We observed mimicry mismatches related to fitness trade-

51 offs, such as reproductive aggregations vs. vulnerability against predators. Despite the general

52 assumption that coevolution of mimicry involves speciation, egg-cowries with different hosts

53 and colorations comprise the same lineages. Consequently, we infer that there would be

54 significant tradeoffs between mimicry and the pursuit of reproductive aggregations in egg-

55 cowries. The findings of this study not only contribute to the understanding of the evolution of

56 mimicry in egg-cowries, a poorly studied group of marine gastropods, but also to the

57 development of a new biologically meaningful board game that could be implemented as a

58 learning tool.

59

60 Key words: Masquerade camouflage, mimicry, octocoral, Pacifigorgia, Neosimnia, Simnia 61 avena, Simnialena rufa, Tropical Eastern Pacific, Chocó, Cabo Corrientes, Malpelo Island, 62 Colombia, evolution games, mitochondrial DNA.

63

64 Background

65

66 Mimicry provides some of the most spectacular outcomes of adaptation and evolution. It is

67 usually a successful adaptation, where background matching provides concealing from predators

68 (Kjernsmo \& Merilaita, 2012) or prey (Stevens \& Merilaita, 2009). However, how mimicry is 
69 achieved and maintained is not entirely understood. It should involve selection and species

70 interactions through many generations, but the evolutionary process itself is difficult to test

71 (Cuthill et al., 2005). Model species exhibiting polymorphisms leading to background

72 mismatches, such as the peppered moth (Van't Hof et al., 2013), are extremely useful to fully

73 understand the evolution and genetics of mimicry. As far we are aware of, no such model for

74 marine organisms has been well described yet.

75

76 There are many remarkable examples of mimicry and camouflage in marine animals. In fishes,

77 for instance, there are repeated cases of mimicry, protective resemblance, and crypsis (Randall,

78 2005). Marine invertebrates such as egg-cowries (Ovulidae:Gastropoda) are recognized

79 symbiotic snails of several kinds of cnidarians (Schiaparelli et al., 2005; Reijnen, Hoeksema \&

80 Gittenberger, 2010), whose coloration includes aposematic and camouflage patterns (Rosenberg,

81 1992; Lorenz \& Fehse, 2009). Egg-cowries and true cowries exhibit special structures on the

82 mantle (compound papillae), which accurately reconstruct the polyps and other structures of

83 cnidarians (Gosliner \& Behrens, 1990; Schiaparelli et al., 2005). It is presumed that part of the

84 camouflage ability in cowries is due to developmental plasticity (Rosenberg, 1992), though a

85 genetic component could also be involved, presumably very variable among the different types

86 of cowries (Vermeij, 2012). The case of camouflage strategy exhibited by egg-cowries is a clear

87 example of adaptive resemblance (Starrett, 1993), and it can be classified as a kind of

88 'masquerade'. It is a background matching mimicry where the subject is slightly different to the

89 background but if it is only glimpsed at, it is not recognized as an edible subject different from

90 the background (Endler, 2006; Stoddard, 2012). This is the case of the ovulids genera Simnia and 
91 Simnialena associated to octocorals of the genera Pacifigorgia, Eugorgia, and Leptogorgia at the

92 Tropical Eastern Pacific-TEP (Sánchez, 2013).

93

94 Octocorals comprise some of the most conspicuous benthic organisms at rocky infralittorals

95 throughout the TEP. Sea fans, sea whips, and sea candelabrum corals are dominant features on

96 hard substrates in this area, reaching densities between 2 and 30 colonies $\mathrm{m}^{-2}$ (Sánchez et al.,

97 2014). Compared with only one species in the Atlantic, sea fans (Pacifigorgia spp.) seem to be

98 particularly fit for the TEP, where they add up to about 35 species in tropical and subtropical

99 waters (Vargas, Guzman \& Breedy, 2008). Although morphological differences among species

100 are very subtle, the color pattern at various traits comprises most of the interspecific variation

101 (Breedy \& Guzman, 2002). This may impose an adaptive challenge for their associated fauna,

102 since most crustaceans and cowries seen on Pacifigorgia spp. match their colors (J.A. Sánchez,

103 personal observation).

104

105 In this research, we studied the association between Simnia/Simnialena and octocorals in a

106 system that includes three octocorals (two seafans and one seawhip) present at the oceanic island

107 of Malpelo, Colombia (Sánchez et al., 2012) and over 10 sympatric sea fan and sea whip species

108 in Cabo Corrientes, a coastal locality in Chocó, Colombia (Sánchez \& Ballesteros, 2014),

109 including the closely related genera of Pacifigorgia, Eugorgia and Leptogorgia. Our study was

110 inspired by the remarkable accuracy of the camouflage strategy of egg-cowries inhabiting

111 different octocoral hosts at the TEP. Are these specialized ectoparasites matching the host

112 species diversity? In other words, does one egg-cowrie species colonize only one octocoral

113 species, or several? Using observations in the field and molecular systematics, we tested the 
114 hypothesis whether egg-cowrie shell (color and shape) polymorphisms, that currently are

115 categorized as distinct species, correspond to different lineages (most likely due to a

116 coevolutionary process) or, alternatively, plasticity or any other mechanism for maintaining

117 polymorphism in shape and coloration within an interbreeding population could explain the

118 phenotypic diversity observed in this group. Given the mimicry specialization observed between

119 egg-cowries and coral hosts at lower taxonomic levels (e.g., genera), data supporting this

120 hypothesis may provide great insight on the link between micro and macro-evolution of

121 background matching as a camouflage strategy.

122

123 The study of this rather simple but unique system may provide important data on how color

124 polymorphisms could be retained in mimicry and may contribute to the understanding of the

125 natural processes leading to camouflage adaptation in marine organisms. This study had two

126 main goals: (1) the description of host preference of different color variants of egg-cowries found

127 in different octocoral species and (2) an assessment of the phylogenetic relationship among egg-

128 cowries with particular emphasis on those that share closely related octocoral hosts. We surveyed

129 egg-cowries at two localities in the Colombian Pacific (Malpelo Island and Cabo Corrientes) and

130 conducted multiyear, detailed preference observations in one of the two locations (Malpelo

131 Island). Inspired in our observations, and in order to integrate our outreach strategy with our

132 research, we developed a board game where evolutionary and ecological themes, such as natural

133 selection and adaptation, are implicit. The ultimate goal of this game was to facilitate the

134 understanding of evolutionary processes, such as adaptation and natural selection, through a

135 ludic activity that could be easily implemented in a learning setting.

136 
138

139

140

141

142

143

144

145

146

147

148

149

150

151

152

153

154

155

156

157

158

159

\section{Methods}

Study areas. Between 2009 and 2012 using SCUBA diving we surveyed two localities at the Colombian Pacific (Fig. 1), Malpelo Island and Cabo Corrientes. Malpelo Island (40N$81^{\circ} 36^{\prime} 20^{\prime}$ W, Fig. 1A) is an oceanic rock escarpment $500 \mathrm{~km}$ off the continental coast of Colombia, which has been declared a conservation-dedicated national sanctuary since 1995 and a UNESCO Heritage area since 2006 (Chasqui Velasco, Gil-Agudelo \& Nieto, 2011). There are only two sea fan species in Malpelo Island, Pacifigorgia cairnsi (Breedy and Guzman 2003) and Pacifigorgia cf. curta (Breedy and Guzman 2003), which reach an average density of 4 colonies $\mathrm{m}^{-2}$ between 5 and $30 \mathrm{~m}$ depth around the island rocky littorals (Sánchez et al., 2012). The two species serve as a camouflage background for egg-cowries (Sánchez, 2013). The sea whip Leptogorgia alba is present in areas below $20 \mathrm{~m}$ and it also carries egg-cowries. As with many isolated oceanic islands, Malpelo has several endemic species ( 5 terrestrial and 7 marine) and particular ecological conditions (López-Victoria \& Werding, 2008) that provide a unique natural experimental setting to study evolution. Endemic fish species include the Rubinoff's triplefin Axoclinus rubinoffi and twinspot triplefin Lepidonectes bimaculata, potential predators of small invertebrate such as egg-cowries (Chasqui Velasco, Gil-Agudelo \& Nieto, 2011). We surveyed and sampled two reefs around Malpelo Island (El Arrecife and La Nevera) (Fig. 1A). The other locality studied corresponds to Cabo Corrientes, in Chocó, at the Pacific coast of Colombia (Fig. 1B). The environmental conditions in this area are quite different compared to Malpelo Island due to constant run-off from one of the most humid areas in the world, yet, the octocoral community in this rocky region is more diverse than in Malpelo (Barrero-Canosa, Dueñas \& 
160 Sánchez, 2012). There are at least 10 octocoral species including mostly sea fans (Pacifigorgia)

161 and a few species of Leptogorgia and Eugorgia, which all carry associated egg-cowries. The

162 octocoral community has been recently affected by the invasive snow flake coral Carijoa riisei,

163 which has decimated octocoral diversity including near local extinction of some octocorals such

164 as Muricea spp. (Sánchez \& Ballesteros, 2014). In Malpelo Island as well as in Cabo Corrientes,

165 water temperature usually does not exceed $27^{\circ} \mathrm{C}$ but there is a marked upwelling season between

166 February and April, when water temperature can be as low as $17^{\circ} \mathrm{C}$ (Sánchez et al., 2014).

167

168 Host preference observations. In 2008, 2009, and 2010 we surveyed four reefs at Cabo

169 Corrientes (Roñosa, Piedra Bonita, Parguera, and Caló) (Fig. 1B). Observations and collection of

170 egg-cowrie specimens on octorals were carried out for at least a 30 minutes dive per site per

171 year. Sampling effort and observations in Malpelo Island were more intensive. Between 2009

172 and 2010 two divers using SCUBA carried out egg-cowries and hosts surveys twice a year at the

173 reefs El Arrecife and La Nevera (Malpelo Island) between 5 and $35 \mathrm{~m}$ depth, where permanent

174 transects and tags for 174 Pacifigorgia colonies eased the biannual observations. Despite the

175 high density of Pacifigorgia sea fans encountered in these surveys (Sánchez et al., 2012), the

176 presence of egg-cowries and their encapsulated ovopositions were inconsistently and rarely

177 spotted. Since some of the surveys were repeated at the same locations and depths, we realized

178 that egg-cowries exhibit a gregarious pattern. In addition, our quantitative method, though fast

179 and representative for surveying sea fans, was inaccurate for spotting Simnia/Simnialena egg-

180 cowries and ovopositions given their small size and camouflage, which makes them very

181 difficult to detect by eye in short surveys. Consequently, one more diver was added to the survey

182 team in 2012 and 2013, whose main goal was thoroughly search for egg-cowries on sea fans 
183 behind the divers surveying Pacifigorgia following the same tagged colonies. This method

184 offered accurate information on their temporal, depth, and host preferences, including

185 ovoposition. Most egg-masses were recorded with digital macro images (Nikon ${ }^{\mathrm{TM}}$ D7000,

186 Nikkor micro $60 \mathrm{~mm}$ lens, Sea $\& \mathrm{Sea}^{\mathrm{TM}}$ YS-D1 strobe and Aquatica ${ }^{\mathrm{TM}}$ AD7000 housing).

187

188 Taxonomic identification and molecular phylogeny reconstruction of egg-cowries. We

189 collected complete individuals of egg-cowries and tissue samples of their octocoral hosts

190 (Research permit No. 105 (2013), Autoridad Nacional de Licencias Ambientales-ANLA,

191 Ministerio de Ambiente y Desarrollo Sostenible, Colombia). All samples were preserved

192 separately in $96 \%$ ethanol and stored in the laboratory at $-20{ }^{\circ} \mathrm{C}$. We obtained a merged image of

193 the dorsal and ventral view of each snail shell using a stereo-microscope camera and the software

194 CombineZP (last accesed on October 5, 2015, www.hadleyweb.pwp.blueyonder.co.uk).

195 Identification of egg-cowries to the lowest taxonomic level possible was achieved following the

196 descriptions by Lorenz \& Fehse, 2009 and Cate, 1973. For the octocorals we compared the

197 vouchers with previously identified material deposited in the Museo de Historia Natural of the

198 Universidad del los Andes (Sánchez et al., 2012, 2014). Total genomic DNA of each specimen

199 was extracted from about $5 \mathrm{~mm}^{2}$ of tissue following a standard CTAB

200 Phenol:Chloroform:Isoamyl Alcohol protocol (Coffroth et al., 1992). DNA quality was assessed

201 in 1\% agarose gel electrophoresis in $1 \mathrm{X}$ TBE buffer. Gels were dyed with ethidium bromide and

202 visualized in a Gel Doc ${ }^{\mathrm{TM}}$ XR (Biorad, U.S.). An approximate estimation of concentration in ng

$203 \mu \mathrm{l}^{-1}$ and purity (260/280 and 260/230 ratios) of each DNA sample was assessed with a NanoDrop

204 (Thermo Scientific, U.S.). We amplified the egg-cowries' mitochondrial genes cytochrome

205 oxidase I (COI) and ribosomal large sub-unit (16S) using the primer pairs COI HCO-2198 (5'- 
206 TAA ACT TCA GGG TGA CCA AAA ATC A -3') and LCO-1490 (5'- GGT CAA CAA ATC

207 ATA AAG ATA TTG G -3’) (Folmer, O., M. Black, W. Hoeh, R. Lutz y R. Vrijenhoek, 1994), 208 and 16S-br (5'- CCG GTC TGA ACT CAG ATC ACG T -3') and 16S-ar (5'- CGC CTG TTT

209 ATC AAA AAC AT -3') (Palumbi, 1996). PCR reactions were performed in a C1000

210 Thermocycler (Biorad, U.S.). All PCR reactions had a final volume of $15 \mu$ including $1 \mathrm{X}$ buffer, $2113.5 \mathrm{mM}$ of $\mathrm{MgCl}_{2}, 0.2 \mathrm{mM}$ dNTPs, $0,8 \mu \mathrm{g} / \mu \mathrm{l}$ of Bovine Serum Albumin, $1 \mu \mathrm{M}$ of each primer,

212 1U of Taq polymerse, and 1-20 ng/ $\mu$ l of total DNA; the PCR profile started with an initial

213 denaturation at $94^{\circ} \mathrm{C}$ for 5 min., 35 cycles at $94{ }^{\circ} \mathrm{C}$ for $1 \mathrm{~min} ., 44^{\circ} \mathrm{C}$ for $30 \mathrm{sec}$. and $72{ }^{\circ} \mathrm{C}$ for 1

214 min., with final extension at $72{ }^{\circ} \mathrm{C}$ for $7 \mathrm{~min}$. PCR products were verified in $1.3 \%$ agarose gel

215 electroporesis in $1 \mathrm{X}$ TBE buffer; expected size of the amplified DNA regions were $710 \mathrm{bp}$ for

$216 \mathrm{COI}$ and $570 \mathrm{bp}$ for $16 \mathrm{~S}$. Contaminants remaining in the PCR products were removed following

217 an alcohol-EDTA cleaning protocol. Sense and antisense strains of each amplified DNA region

218 were sequenced using a Biosystems BigDye 3.1 kit and a capillary electrophoresis automated

219 sequencer AB310 (Applied Biosystems). Raw electropherograms were checked visually using

220 the software Geneious v4.8 (Drummond et al., 2009). Contigs and consensus sequences of each

221 gene were also obtained using Geneious v4.8. We verified the overall taxonomic identity of the

222 obtained sequences with the Basic Local Alignment Search Tool, BLAST (NCBI, U.S.).

223 Sequence alignment, concatenation, and phylogenetic analyses were done in Geneious v8.0.4,

224 including the implemented packages for maximum parsimony (PAUP*), maximum likelihood

225 (RAxML) and Bayesian inference (MrBayes), the last two analyses using the GTR model of

226 sequence evolution as recommended by RAxML (Stamatakis, 2015) and default settings for

227 getting 1000 replicates of bootstrapping node support. A sequence from the Caribbean flamingo

228 tongue (Cyphoma gibbosum:Ovulidae) was included as outgroup. 


\section{Integrated outreach: The masquerade game}

231 Inspired by the results obtained in this study, as well as on some elements of the classroom kits

232 from the California Academy of Sciences, the "Coral Reef: Science and Conservation Game-

233 The fragile coral reef (grades 3-7)" (Teaching and Student Services, 2008), we conceived a board

234 game based on the mimicry adaptation of egg-cowries to coral hosts, which we think is useful for 235 illustrating evolution and ecology concepts (see Supplementary Material for details and a game 236 kit).

\section{Results}

239 Host preference in egg-cowries

240 Egg-cowries in Cabo Corrientes and Malpelo Island colonized all surveyed octocoral species of

241 Leptogorgia, Pacifigorgia and Eugorgia (Table 1, Figs. 2-3). Large (>10 individuals)

242 reproductive aggregations were observed on Pacifigorgia irene, one of the most abundant sea

243 fans at Cabo Corrientes (Fig 2A). Overall, all collected egg-cowries matched their mantle color

244 pattern with those of the octocoral host; the shape and color of the snails associated to

245 Pacifigorgia and Eugorgia were noticeably different respect to the snails associated to

246 Leptogorgia, the first showing a red-purplish robust shell and the latter a white-pinkish elongated 247 shell (Fig. 2).

249 Detailed observations at Malpelo Island revealed that about $10 \%$ of the 174 tagged colonies have 250 at least one egg-cowrie and 4\% can have an ovoposition, which corresponded to roughly 0.01 251 and 0.04 egg-cowries or ovopositions per square meter assuming a seafan density of $4 \mathrm{col} \mathrm{m} \mathrm{m}^{-2}$ 
252 (Sánchez et al., 2012). Egg-cowries display a nearly perfect 'masquerade' background, matching

253 the appearance of the sea fan Pacifigorgia by having polyp-like structures coming off the

254 gastropod mantle (Fig. 3). There are only two species of sea fans in the infralittoral region of

255 Malpelo Island, one has a red coenenchyme (octocoral branch tissue) with white polyps

256 (Pacifigorgia cairnsi) and the other one has a blue-purplish coenenchyme with white, pink, or

257 orange polyps (Pacifigorgia cf. curta). We observed that Pacifigorgia cf. curta egg-cowries

258 match the background of the three polyp types present in these sea fans (Fig. 3A-C). The polyps

259 of the sea fans are active most of the day, but when they are not, the sea fan background changes

260 to the color of the coenemchyme. In this case egg-cowries have to retract their mantle and the

261 color of their shell provides mimicry. In the 174 tagged colonies, we observed less than 5

262 mismatches between shell color and coenenchyme color and those individuals usually moved

263 towards the base of the colony. Other mismatches were observed during the reproductive period.

264 The background matching of egg-cowries also included the color of the ovoposition, which is

265 deposited as encapsulated eggs on sea fan branches (Fig. 4A-C). In this trait, mismatches were

266 commonly seen during group mating at the zone of interaction of the two seafan species (Fig.

267 4A-C). This behavior could increase the chance of interbreeding among different egg-cowries

268 species associated to a similar type of octocoral. In Malpelo Island group ovopositions were

269 observed in July, March, and November. The two sea fan species in Malpelo Island are usually

270 distributed at different depth ranges (Pacifigorgia cf. curta shallow, 3-10 m, and P. cairnsi deep,

$271 \quad 10-30 \mathrm{~m})$. We observed that snails with background mismatches were present at the boundary

272 where the distribution of the sea fan species (Pacifigorgia cairnsi and P. cf. curta) coincide, or in

273 overlapping areas where they coexist.

274 
275 Given our observations of the egg-cowries natural history, we can hypothesize that background

276 matching is under selection because there are many potential natural predators that can take

277 advantage of mismatches. For instance, hawkfishes, predators of small invertebrates (Froese \&

278 Pauly, 2015), were frequently seen near sea fan colonies with egg-cowries (Fig. 5A-B). The

279 longnose hawkfish (Oxycirrhites typus) is adapted to hunt small invertebrates found on octocoral

280 and black coral branches and comes in close contact with egg-cowries as it also settles on sea

281 fans (Fig. 5A). The coral hawkfish (Cirrhitichthys oxycephalus) also patrols for small prey on the

282 substrate in close contact with sea fans (Fig. 5B). Although these fish do not have a fixed

283 territory, they spend enough time around sea fans to spot and take advantage of mismatched

284 cowries.

285

286 Our observations suggest that color variants of egg-cowries could move freely throughout the

287 two Pacifigorgia species in the island. Sea fans of these two species were as near as 1-5 mm

288 from each other at their overlapping depth interval $(4-10 \mathrm{~m})$. This implies that egg-cowries could

289 go from one colony to another without leaving their hosts. Given the abundance of predators,

290 there should be a trade-off between reproduction and protection against predation in egg-

291 cowries.

292

293 We observed additional threats to egg-cowries survival related to habitat destruction, i.e., sea fan

294 mortality. During the years of this survey (2009-2012) two sources of sea fan mortality were

295 noted in Malpelo Island, fungal diseases and an invasive coral overgrowth. Mass mortalities

296 were observed during 2009 and 2010, sometimes reaching 70\% of sea fans (Sánchez et al.,

297 2012). Affected colonies had the epizootiology of the fungal disease aspergillosis (Fig. 5C) that 
298 has been recently detected elsewhere in the TEP (Barrero-Canosa, Dueñas \& Sánchez, 2012). At

299 two locations in Malpelo Island, 'submarino' (western most point of 'La Nevera') and some

300 isolated rocky islets off the main island ('La Catedral'), large infra-littoral areas are completely

301 covered by the snowflake coral Carijoa riisei (Fig. 5D). This is an invasive octocoral presumably

302 brought from the Western Atlantic, which overgrows and kills sea fans in Malpelo Island and

303 elsewhere in the TEP (Sánchez \& Ballesteros, 2014). Though egg-cowries were seen on sea fan

304 colonies affected by these two stressors, most of them were observed on healthy ones.

305

306 Morphologic and Molecular identification

307 Egg-cowrie surveys revealed a species complex including the nominal species Simnia avena=S.

308 aequalis (G.B. Sowerby II, 1832) fide Lorenz \& Fehse (2009) and, Simnialena rufa=Simnia

309 inflexa (G.B. Sowerby II, 1832) fide Cate (1973) and Lorenz \& Fehse (2009). The S. avena

310 morphology was observed on most Pacifigorgia, Leptogorgia and Eugorgia at Cabo Corrientes,

311 whereas Simnialena rufa was observed on Pacifigorgia sea fans in Malpelo Island. (Table 1).

312 Figure 6 shows the typical morphology of the two nominal egg-cowrie species observed in the

313 Colombian Pacific. In general we encountered challenges in the taxonomic identification of egg-

314 cowries, either because there is not a unified and updated taxonomic key for this group or due to

315 the presence of intermediate morphologies. For instance, egg-cowries in Malpelo Island clearly

316 looked like S. rufa when found on Pacifigorgia cf. curta and more like S. avena on P. cairnsi.

318 A phylogenetic analysis based on the sequence of the mitochondrial genes COI and $16 S$ showed

319 two well supported clades for all the surveyed egg-cowries (Fig. 7). One clade comprised $S$.

320 avena specimens associated to Leptogorgia spp and the other one included egg-cowries found on 
321 Eugorgia and Pacifigorgia, both in Cabo Corrientes and Malpelo Island (Table 1). Within each

322 clade there was neither well-supported sub-clades nor significant sequence divergence (Fig. 7).

323 This result supports the assumption of an important role of developmental plasticity on the

324 variation of camouflage patterns within egg-cowries species.

326

327 Discussion

328

329 Egg-cowries at the Colombian Pacific exhibit a remarkable camouflage strategy, in a 330 masquerade fashion, mimicking over a dozen of octocoral hosts. The negligible genetic

331 divergence observed within clades, that included multiple species and occasionally genera, 332 suggests that developmental plasticity should play an important role on the determination of their 333 delicate masquerade camouflage. Though the remarkable mimicry of egg-cowries has been 334 previously studied, we found no former record on background matching for the encapsulated 335 eggs nor the observed ovoposition mismatches at the zone of interaction of similar sea fan hosts.

336 The main contribution of our natural history observations relies on the recognition of tradeoffs

337 between mimicry and the pursuit of reproductive aggregations in egg-cowries.

339 Previous phylogenetic studies in Ovulidae provide a good framework to situate the evolutionary

340 tempo among TEP egg-cowries. At a large phylogenetic scale, including several Ovulidae

341 genera, cowries show some degree of host specialization within Anthozoa yet several

342 morphologic traits used in taxonomy are polyphiletic (Schiaparelli et al., 2005). Likewise, there

343 is a marked phylogenetic split between Indopacific and Atlantic Ovulidae; still, many groups at 
344 each ocean lacked phylogenetic differentiation (Reijnen, Hoeksema \& Gittenberger, 2010;

345 Reijnen, 2015). Consequently, the paucity of genetic divergence among egg-cowries from

346 closely related octocorals, as seen in our results, is not surprising.

347

348 Mitochondrial DNA genes, such as COI, have been extensively used for the taxonomic

349 identification of mollusks, including ovulids, from different parts of the world (Layton, Martel \&

350 Hebert, 2014; Borges et al., 2016). For cowries, sister group of egg-cowries, COI barcoding has

351 shown a species identification error between 4 and 17\% (Meyer \& Paulay, 2005). Whereas for

352 the egg-cowries, Crenavolva spp., COI and 16S, the same mtDNA genes used in this study,

353 provided enough support for species differentiation and reviewing of the taxonomy of the genus

354 (Reijnen, 2015). The modest phylogenetic divergence of the studied egg-cowries suggests a key

355 role of phenotypic plasticity in the morphological variation.

356

357 Among the consequences of highly specialized parasitism and mimicry of the masquerade type is

358 coevolution with their host. The case of egg-cowries is a nearly perfect masquerade to their

359 octocoral hosts. Just in Malpelo Island there are at least four different color patterns in sea fan

360 polyps that were matched by the egg-cowries. How did the same interbreeding population

361 achieve this color variation? Our observations suggest that reproductive aggregation is a priority

362 over concealment from predators and more importantly, regardless of the mates' color. This

363 behavior is similar to what has been seen in the aposematic ovulid Cyphoma gibbosum for

364 chosing among octocoral hosts (Nowlis, 1993). In addition, this supports the notion that

365 conservation of polymorphisms in this trait would promote faster adaptation. Isolation with gene

366 flow between different colorations of egg-cowries could contribute to maintain color

367 polymorphism, which would promote faster background matching adaptation (Gray \& 
368 McKinnon, 2007). However, the question of how much of the camouflage ability is due to

369 developmental plasticity in response to the environment (host) and how much is due to adaptive 370 genetics (Rosenberg, 1992) remains unsolved.

371

372 The link between phenotypic plasticity and diversification processes remains one of the major

373 questions in evolutionary biology (West-Eberhard, 2003; Fitzpatrick, 2012). Phenotypic

374 plasticity provides the adaptive canvas for further adaptation and speciation. Yet, could

375 phenotypic plasticity promote ecological speciation? Phenotypic plasticity could impede

376 diversification since a single genotype is supposed to give rise to different phenotypes, as we

377 observed in egg-cowries associated to sea fans. We assume phenotypic plasticity is allowing egg-

378 cowries to colonize many hosts in the TEP, for which specialization resembles adaptive

379 divergence or even radiation (Pfennig et al., 2010). Given the potential occurrence of mating 380 among different egg-cowrie morphotypes, a detailed analysis of their adaptive genetic variation

381 using more powerful molecular approaches would be necessary. We consider that the

382 Simnia/Simnialena complex may constitute an ideal marine system to study and test this

383 question.

384

385

386 Conclusions

387 Our study system comprised background-matching mimicry, of the masquerade type, between 388 egg-cowries (Simnia/Simnialena) and octocorals (Pacifigorgia/Eugorgia/Leptogorgia). The 389 ovoposition of the different egg-cowrie color variants also matches the host color. Egg-cowries 390 with different color patterns but associated to similar octocoral hosts can indistinctively gather 
391 for reproductive aggregations in Malpelo Island, which was consistent with their negligible

392 phylogenetic divergence. Egg-cowries show background mismatches in ovoposition, which

393 constitute a particular event that could help to understand how selection operates to refine

394 mimicry traits and promote adaptation. These novel observations inspired us to develop a

395 biologically meaningful game that could facilitate the teaching and learning process of ecology

396 and evolution in the classroom as well as in outreach activities, while increasing the awareness

397 and connection of students with their environment. We invite the readers to play and share this

398 game, available in the supplementary material.

399 Acknowledgements

400 We acknowledge 2009-2012 expeditions to SFF Malpelo Island organized and supported by

401 Fundación Malpelo and Parques Nacionales Naturales (SFF Malpelo), Colombia (Sandra

402 Bessudo and Nancy Murillo). Special thanks to Ciaran Smyth for fruitful insights into the game

403 and help testing the early versions. We appreciate the help from colleagues and students from

404 BIOMMAR for assistant in the field and laboratory Luisa Dueñas, Catalina Ramírez, Diana

405 Ballesteros, Carlos E. Gómez, Fabio Casas, Lina Gutierrez, Elena Quintanilla and Dairo Escobar

406 among others. We apreciate the comments from our reviewers, Joana Robalo and an anonymous

407 reviewer that greatly improved the manuscript. We recognize the participation and support from

408 local communities in Cabo Corrientes. 
409 Table 1. Egg-cowrie specimen information including sample label, collection date, the putative morphologic identification, location

410 and site of collection, depth of collection and coral host, and Genbank accession numbers for $16 S$ and $C O I$ sequences.

\begin{tabular}{|c|c|c|c|c|c|c|c|c|}
\hline $\begin{array}{l}\text { Sample } \\
\text { label }\end{array}$ & $\begin{array}{l}\text { Collection } \\
\text { date }\end{array}$ & Morphologic ID & Location & Site & Depth (m) & $\begin{array}{l}\text { Coral host } \\
\text { species }\end{array}$ & $16 S$ & $\mathrm{COI}$ \\
\hline \multicolumn{9}{|c|}{ Pacifigorgia - Eugorgia clade } \\
\hline K136 & 19-Apr-11 & Simnia sp. & Cabo Corrientes & Caló & 15 & $\begin{array}{l}\text { Pacifigorgia } \\
\text { sculpta }\end{array}$ & KU557467 & KU557450 \\
\hline K175 & 16-Apr-11 & Simnia avena & Cabo Corrientes & Roñosa & 15 & P. stenobrochis & KU557469 & KU557452 \\
\hline K191 & 16-Apr-11 & Simnia avena & Cabo Corrientes & Piedra Bonita & 10 & P. eximia & KU557470 & KU557453 \\
\hline K193 & 16-Apr-11 & Simnia avena & Cabo Corrientes & Roñosa & 12 & Pacifigorgia sp. & KU557471 & KU557454 \\
\hline K237 & 19-Apr-11 & Simnia avena & Cabo Corrientes & Caló & 15 & P. stenobrochis & KU557472 & KU557455 \\
\hline Y098 & 26-Feb-11 & Simnialena rufa & Malpelo Island & La Nevera & 10 & P. cairnsi & KU557473 & KU557456 \\
\hline Y100 & $26-F e b-11$ & Simnialena rufa & Malpelo Island & La Nevera & 10 & $\begin{array}{l}\text { Pacifigorgia sp. } c f \text {. } \\
\text { curta }\end{array}$ & KU557474 & KU557457 \\
\hline Y101 & 26-Feb-11 & Simnialena rufa & Malpelo Island & La Nevera & 10 & P. cairnsi & KU557475 & KU557458 \\
\hline Y109 & 26-Feb-11 & Simnialena rufa & Malpelo Island & El Arrecife & 15 & P. cairnsi & KU557476 & KU557459 \\
\hline Y183 & 18-Apr-11 & Simnia avena & Cabo Corrientes & Piedra Bonita & 12 & Pacifigorgia sp. & KU557477 & KU557460 \\
\hline Y185 & 18-Apr-11 & Simnia sp. & Cabo Corrientes & Piedra Bonita & 12 & Pacifigorgia sp. & KU557478 & KU557461 \\
\hline Y188 & 18-Apr-11 & Simnia avena & Cabo Corrientes & Roñosa & 10 & Eugorgia daniana & KU557479 & KU557462 \\
\hline Y197 & 18-Apr-11 & Simnia avena & Cabo Corrientes & Piedra Bonita & 12 & Pacifigorgia sp. & KU557480 & KU557463 \\
\hline Y199 & 18-Apr-11 & Simnia sp. & Cabo Corrientes & Piedra Bonita & 12 & P. eximia & KU557482 & KU557465 \\
\hline \multicolumn{9}{|c|}{ Leptogorgia clade } \\
\hline K116 & 17-Apr-11 & Simnia avena & Cabo Corrientes & Parguera 7 & 12 & Leptogorgia alba & KU557466 & KU557449 \\
\hline K168 & 16-Apr-11 & Simnia avena & Cabo Corrientes & Roñosa & 5 & L. ramulus & KU557468 & KU557451 \\
\hline
\end{tabular}




\section{Figures}

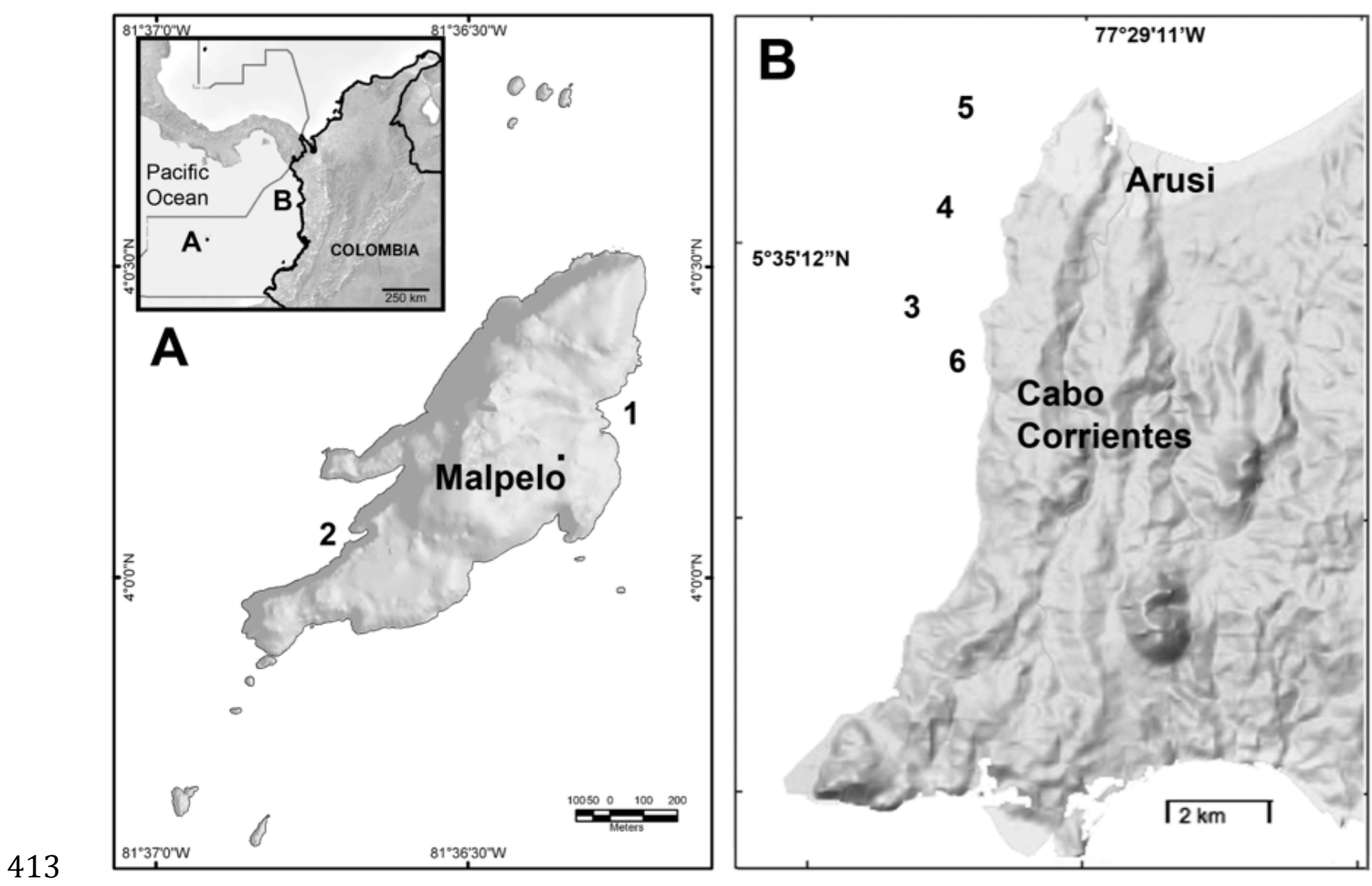

414 Figure 1. Study sites at the Colombian Pacific. A. Malpelo Island (1. El Arrecife; 2. La Nevera).

415 B. Cabo Corrientes, Chocó (3. Roñosa; 4. Piedra Bonita; 5. Parguera 7; 6. Caló). 

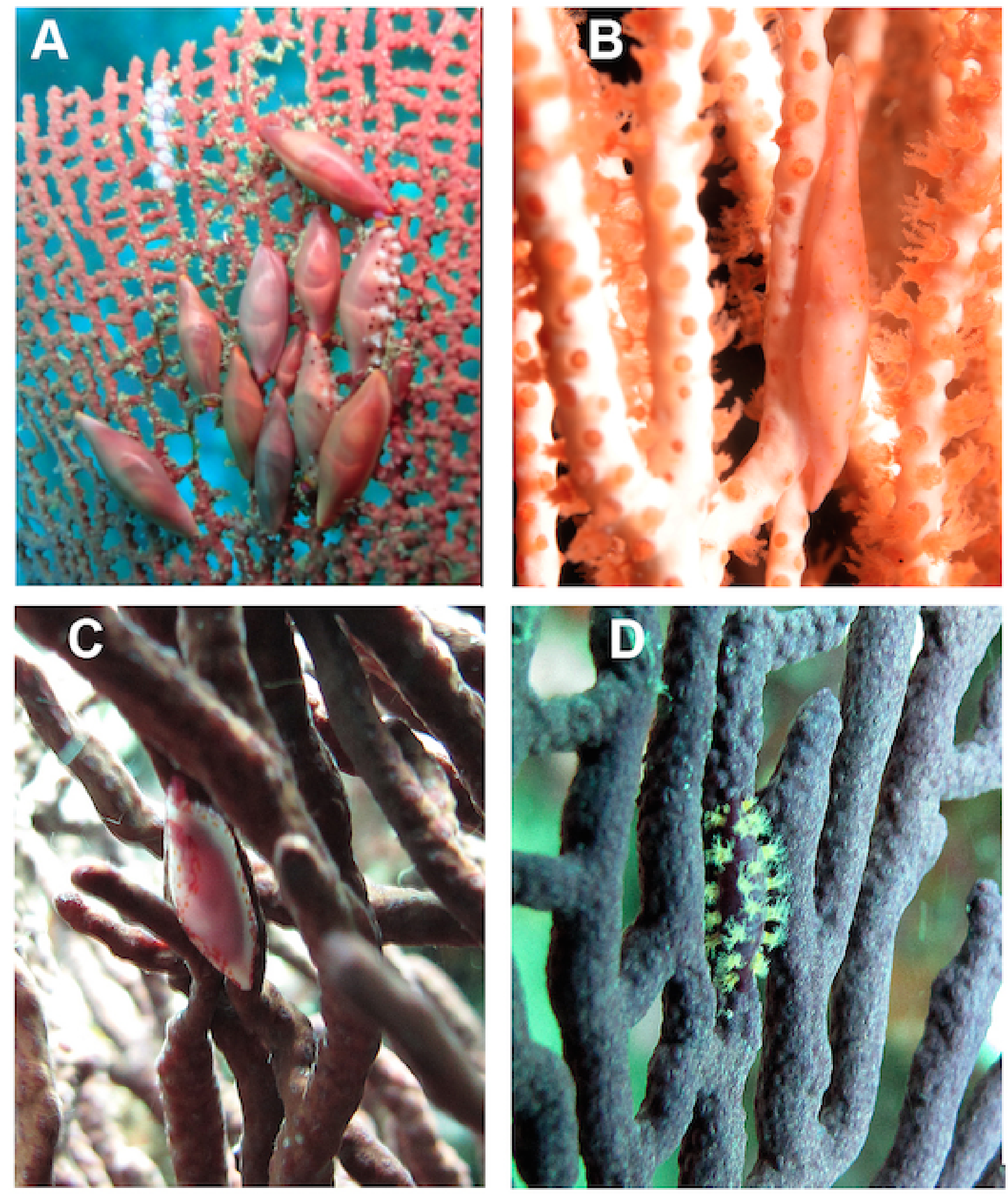

417 Figure 2. Egg-cowries (Ovulidae) observed in the Colombian Pacific (A, C and D in Cabo

418 Corrientes, Chocó; B Malpelo Island). Coral hosts: A. Pacifigorgia irene (depth 12 m), B.

419 Leptogorgia alba (25 m) (Malpelo Island). C. L. ramulus (5 m). D. P. stenobrochis (15 m). 

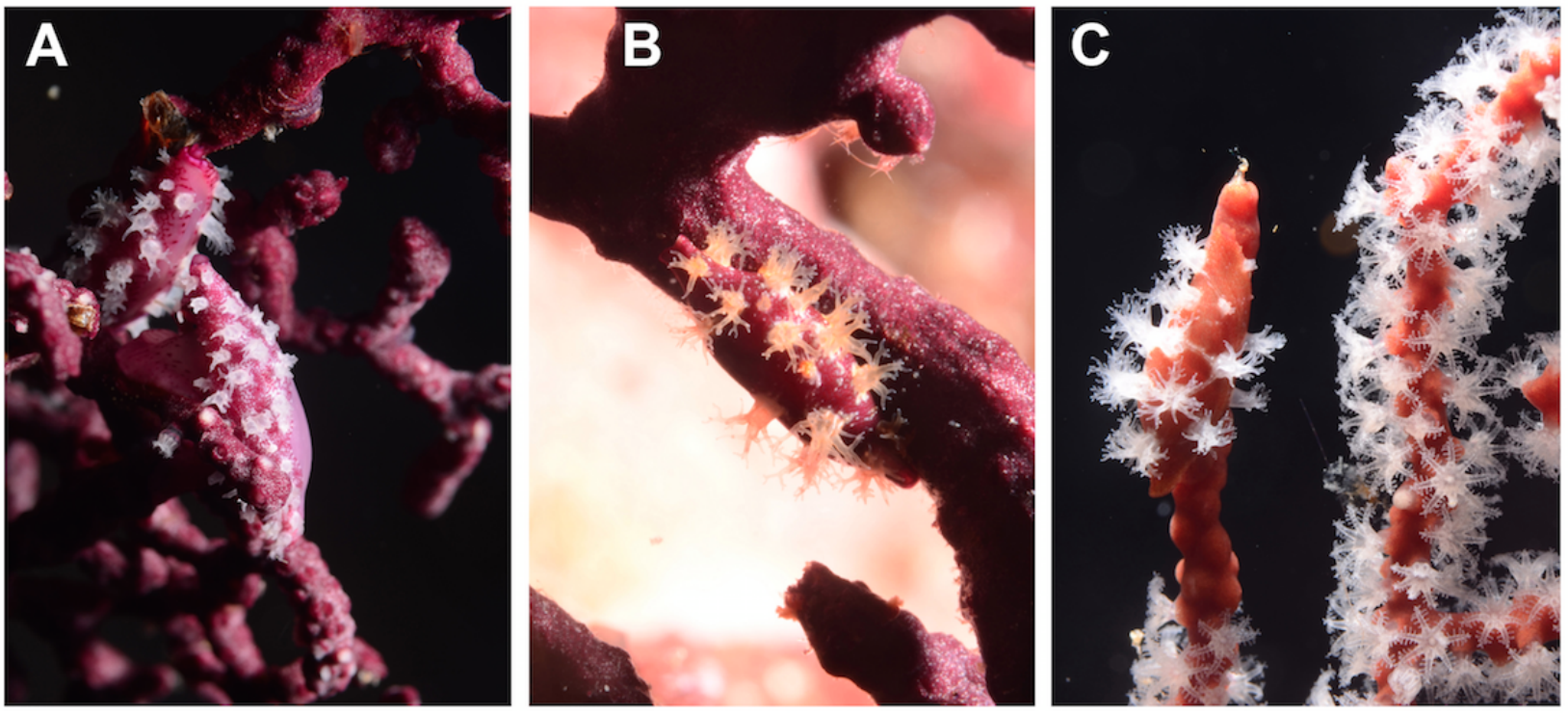

421 Figure 3. Egg-cowrie Simnia avena on Pacifigorgia cairnsi and P. cf. curta at Malpelo Island,

422 Colombian Pacific. (A) S. avena on P. cf. curta -white polyps; (B) S. avena on P. cf. curta -

423 orange polyps; (C) S. avena on P. cairnsi.
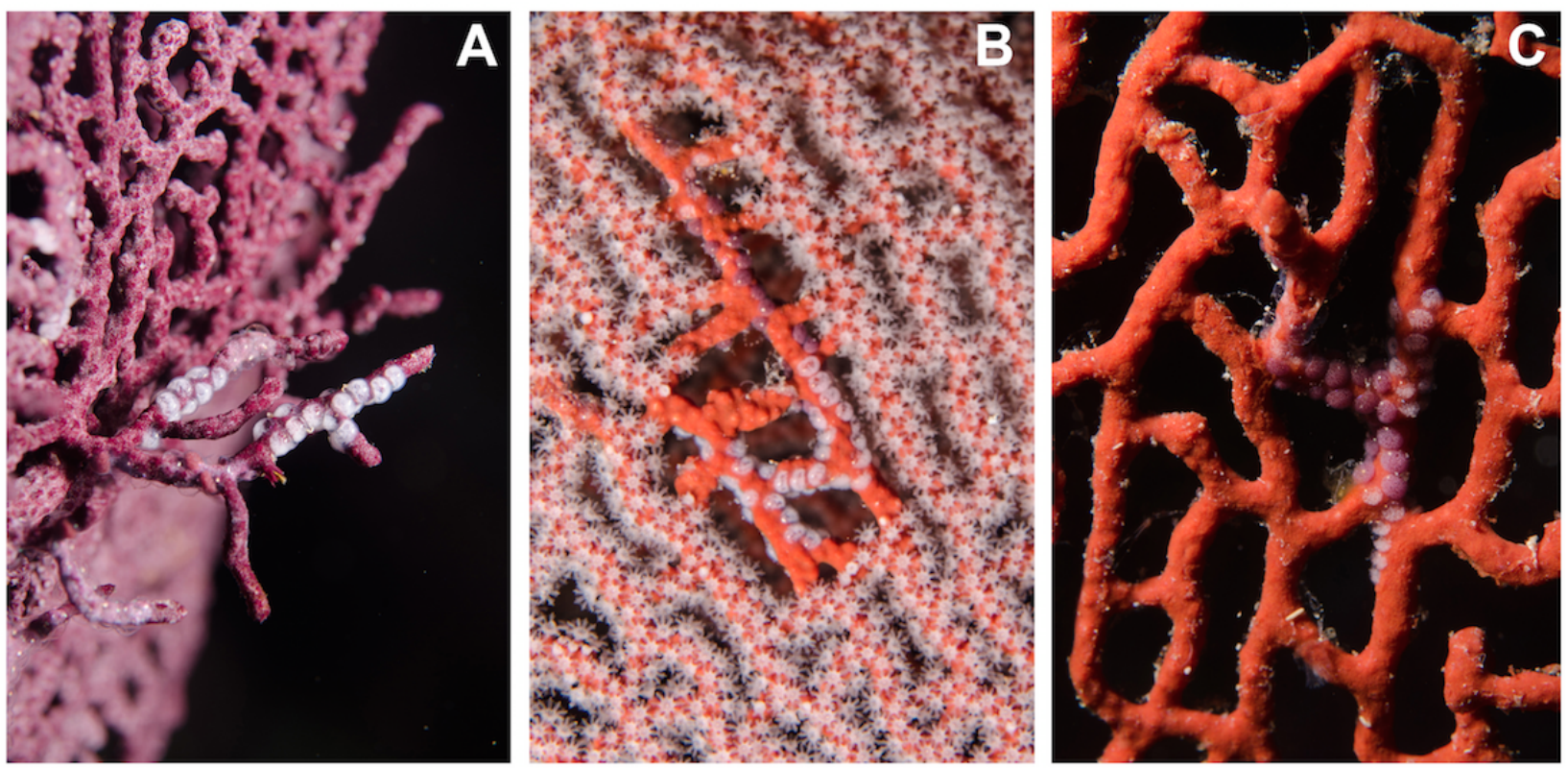

425 Figure 4. Mixed ovopositions (white and purple) left by the cowrie Simnia avena on sea fans at

426 Malpelo Island, Colombian Pacific.Pacific. A. Mixed ovoposition on purple background,

427 Pacifigorgia cf. curta; (B-C) mixed ovoposition on red background, P. cairnsi. 

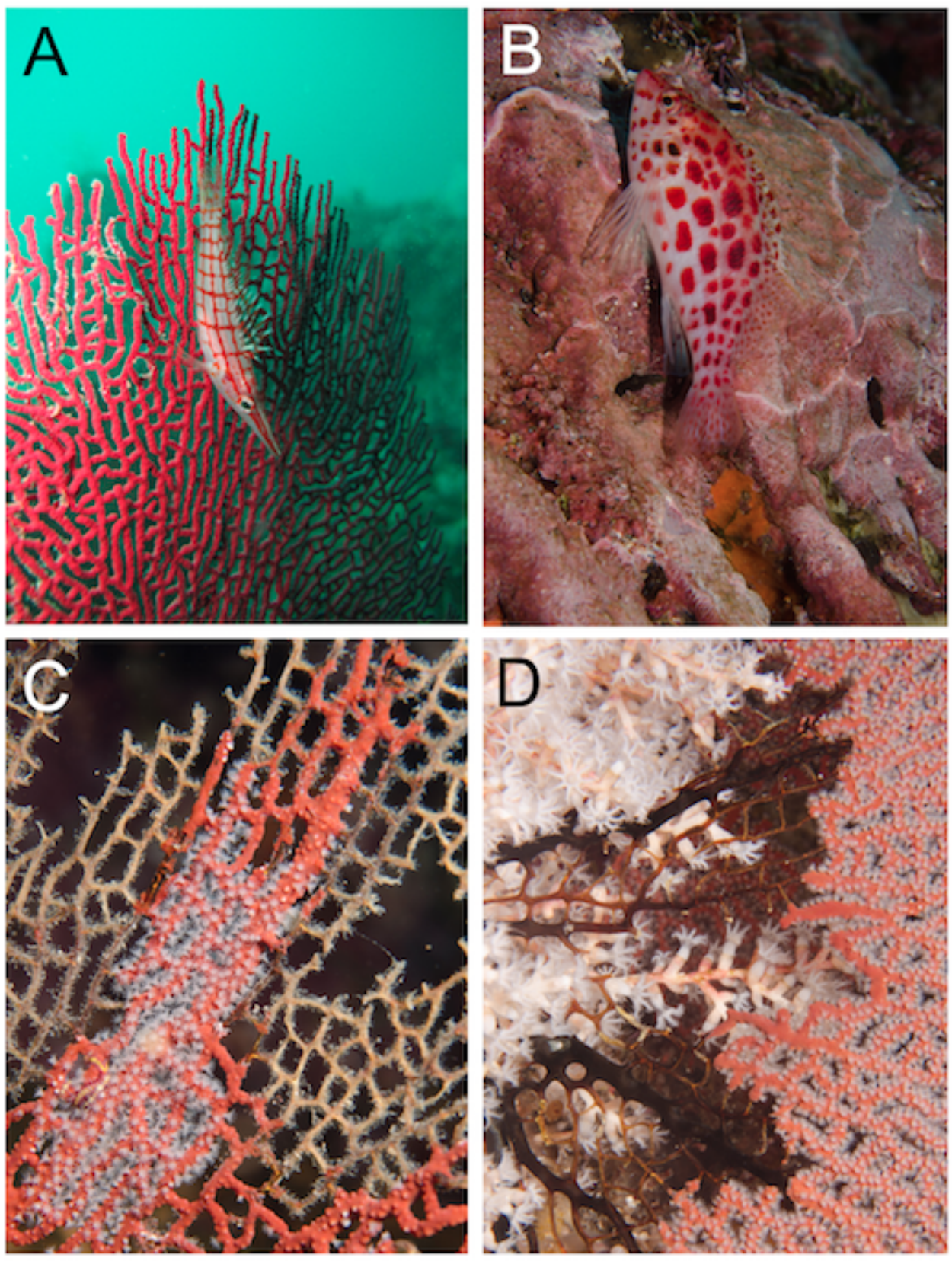

429 Figure 5. Potential threats to Simnia egg-cowries at Cabo Corrientes and Malpelo Island, Eastern

430 Tropical Pacific, Colombia. (A) Longnose hawkfish Oxycirrhites typus with a sea fan-like

431 background camouflage (Cabo Corrientes); (B) Coral hawkfish Cirrhitichthys oxycephalus; (C)

432 Diseased sea fan Pacifigorgia cairnsi; (D) The invasive snowflake coral, Carijoa riisei,

433 overgrowing P. cairnsi (B-D Malpelo Island). 

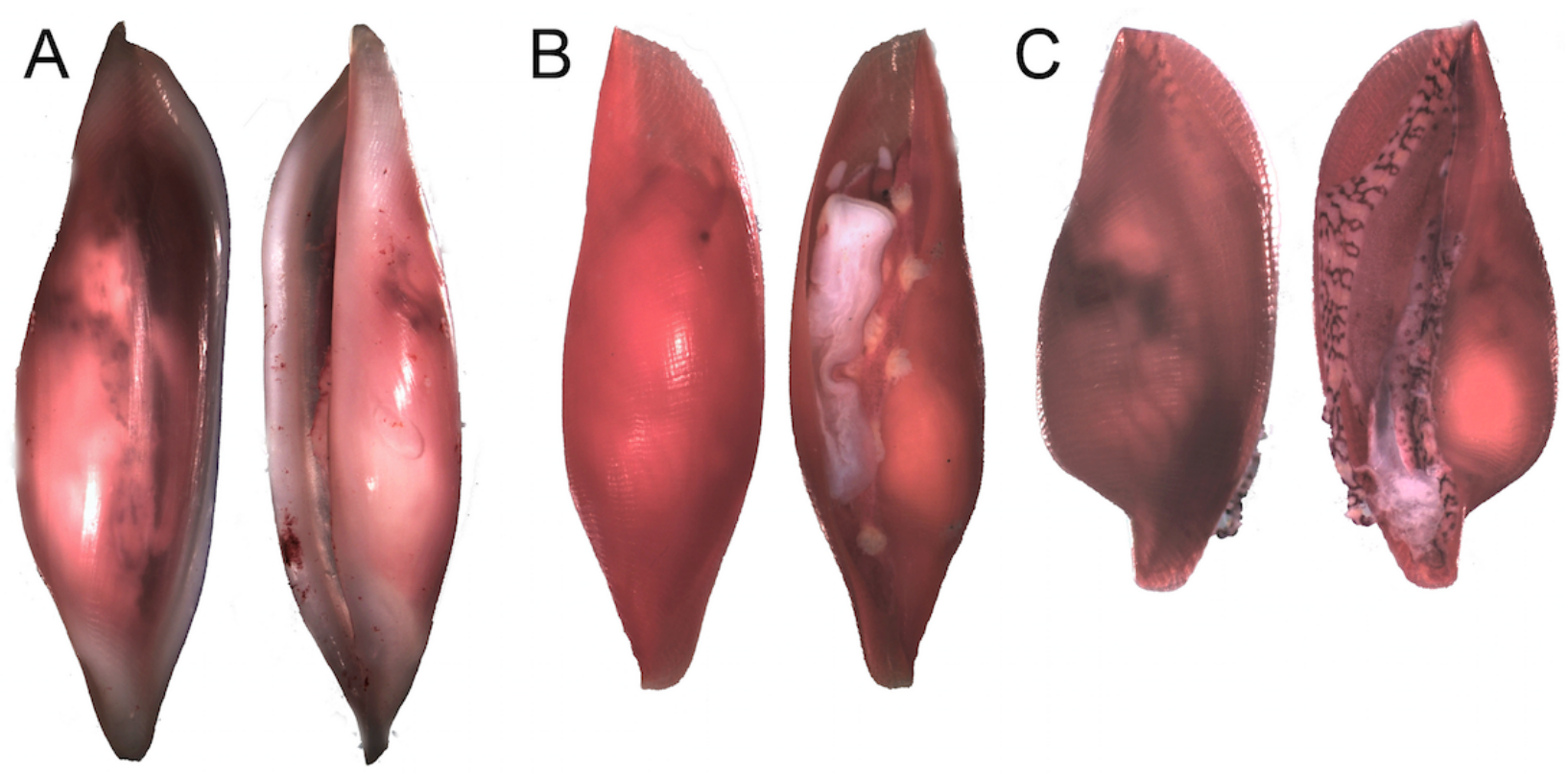

436 Figure 6. Distinct shell morphologies found in egg-cowries at the Colombian Pacific. A. Simnia 437 avena, adult specimen K168 found on Leptogorgia ramulus at Cabo Corrientes, $12.6 \mathrm{~mm}$ (max 438 length). B. Simnia avena, juvenil specimen K191 found on Pacifigorgia eximia, Cabo 439 Corrientes, $5.8 \mathrm{~mm}$. C. Simnialena rufa, Y100, on Pacifigorgia cf. curta, Malpelo Island, $4 \mathrm{~mm}$. 440 


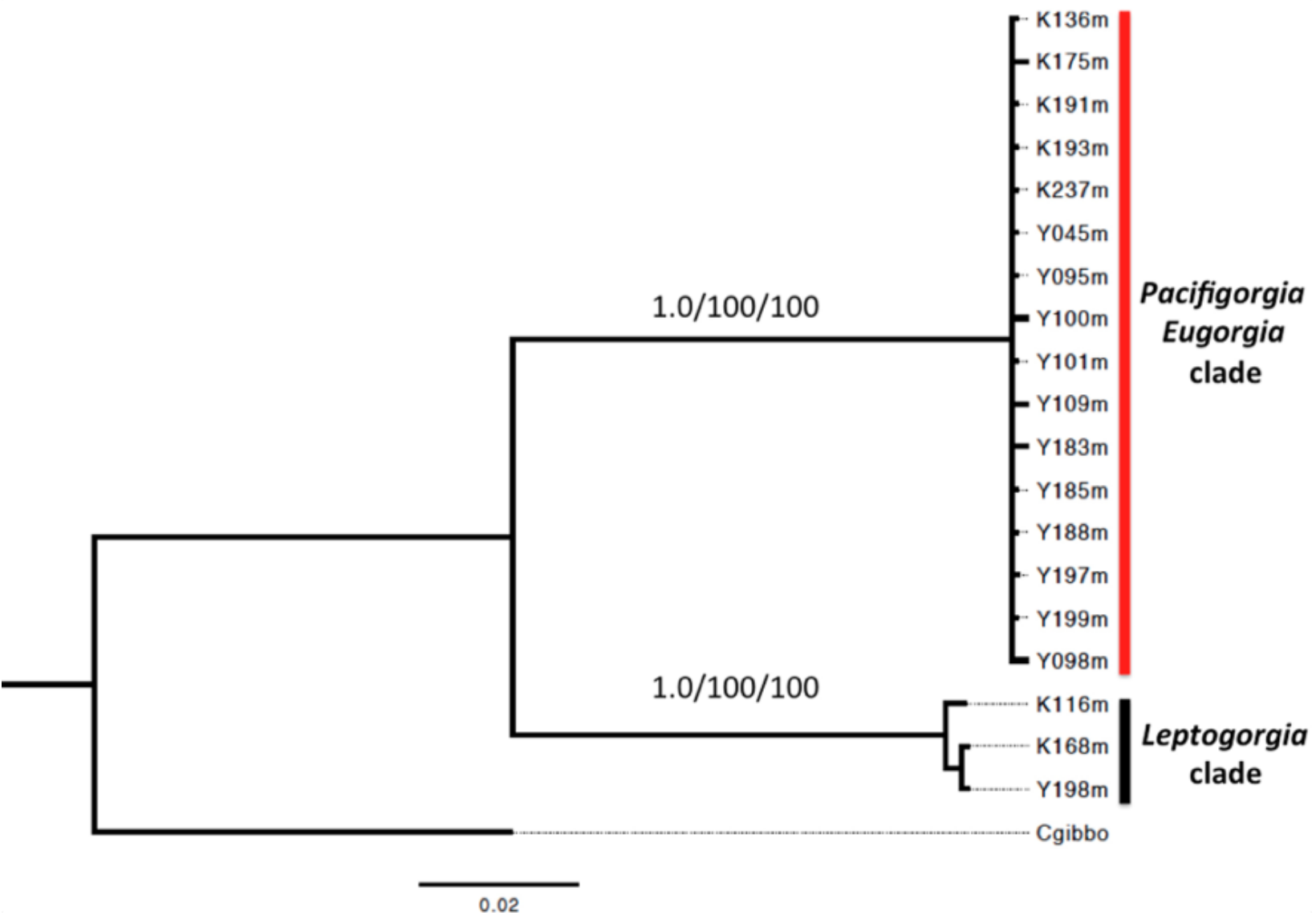

442 Figure 7. Bayesian inference phylogram using concatenated $16 S$ and COI mitochondrial

443 sequences. Above node support are presented for 1000-replicates bootstrapping values $>0.7$

444 (Bayesian posterior probabilities) and $>70 \%$ maximum parsimony/maximum likelihood.

445

446

447

448

449

450

451

452 


\section{References}

454

455

456

Bandel K. 1973. Notes on Cypraea cinerea Gmelin and Cyphoma gibbosum (Linnaeus) from the Caribbean Sea and description of their spawn. Veliger 15:335-337.

Barrero-Canosa J., Dueñas LF., Sánchez JA. 2012. Isolation of potential fungal pathogens in 458 gorgonian corals at the Tropical Eastern Pacific. Coral Reefs 32:35-41. DOI:

459 10.1007/s00338-012-0972-2.

460

461

462

463

Béarez P., Bujard J-T., Campoverde R. 2007. Description of four small reef fishes from Ecuador: Oxycirrhites typus (Cirrhitidae), Acanthemblemaria balanorum (Chaenopsidae), Arcos decoris (Gobiesocidae) and Lythrypnus dalli (Gobiidae). Cybium 31:477-479.

Borges LM., Hollatz C., Lobo J., Cunha AM., Vilela AP., Calado G., Coelho R., Costa AC., Ferreira MS., Costa MH. 2016. With a little help from DNA barcoding: investigating the diversity of Gastropoda from the Portuguese coast. Scientific Reports 6.

Breedy O., Guzman HM. 2002. A revision of the genus Pacifigorgia (Coelenterata: 115:782-839.

Calcinai B., Bavestrello G., Cerrano C. 2004. Dispersal and association of two alien species in the Indonesian coral reefs: the octocoral Carijoa riisei and the demosponge Desmapsamma anchorata. Journal of the Marine Biological Association of the United Kingdom 84:937-941.

474 Cate CN. 1973. A systematic revision of the recent cypraeid family ovulidae (Mollusca: 475 Gastropoda). California Malacozoological Society. 
476 Chasqui Velasco L., Gil-Agudelo DL., Nieto R. 2011. Endemic shallow reef fishes rom

477 Malpelo island: abundance and distribution. Boletín de Investigaciones Marinas y $478 \quad$ Costeras-INVEMAR 40:107-116.

479 Coffroth MA., Lasker HR., Diamond ME., Bruenn JA., Bermingham E. 1992. DNA fingerprints 480 of a gorgonian coral: A method for detecting clonal structure in a vegetative species. $481 \quad$ Marine Biology 114.

482 Cuthill IC., Stevens M., Sheppard J., Maddocks T., Párraga CA., Troscianko TS. 2005.

483 Disruptive coloration and background pattern matching. Nature 434:72-74.

484 Drummond AJ., Ashton B., Cheung M., Heled J., Kearse M., Moir R., Stones-Havas S., Thierer 485 T., Wilson A. 2009. Geneious 4.8. Biomatters, Auckland, New Zealand.

486 Endler JA. 2006. Disruptive and cryptic coloration. Proceedings of the Royal Society B: Biological Sciences 273:2425-2426.

488

489

490

491

492

493

494

495

496

497

Fitzpatrick BM. 2012. Underappreciated consequences of phenotypic plasticity for ecological speciation. International Journal of Ecology 2012.

Folmer, O., M. Black, W. Hoeh, R. Lutz y R. Vrijenhoek R. 1994. DNA primers for amplification of mitochondrial cytochrome c oxidase subunit I from diverse metazoan invertebrates. Molecular marine biology and biotechnology 3:294-299.

Froese R., Pauly D. 2015. Fish Base. World Wide Web, Electronic Publication. http://www. fishbase. org.

Gosliner TM., Behrens DW. 1990. Special resemblance, aposematic coloration and mimicry in opisthobranch gastropods. Adaptive coloration in invertebrates. Texas A\&M University Sea Grant College Program, College Station:127-138. 
498 Gray SM., McKinnon JS. 2007. Linking color polymorphism maintenance and speciation.

499 Trends Ecol Evol 22:71-9. DOI: 10.1016/j.tree.2006.10.005.

500 Kjernsmo K., Merilaita S. 2012. Background choice as an anti-predator strategy: the roles of 501 background matching and visual complexity in the habitat choice of the least $502 \quad$ killifish. Proceedings of the Royal Society B: Biological Sciences:rspb20121547.

503 Layton KK., Martel AL., Hebert PD. 2014. Patterns of DNA barcode variation in Canadian $504 \quad$ marine molluscs. PloS one 9:e95003.

505 Long DE. 2012. The politics of teaching evolution, science education standards, and being a 506 creationist. Journal of Research in Science Teaching 49:122-139.

507 López-Victoria M., Werding B. 2008. Ecology of the Endemic Land Crab Johngarthia 508 malpilensis (Decapoda: Brachyura: Gecarcinidae), a Poorly Known Species from the 509 Tropical Eastern Pacific 1. Pacific Science 62:483-493.

510 Lorenz F., Fehse D. 2009. The living Ovulidae: a manual of the families of allied cowries: Ovulidae, Pediculariidae and Eocypraeidae. ConchBooks.

512 Meyer CP., Paulay G. 2005. DNA barcoding: error rates based on comprehensive sampling. 513 PLoS biol 3:e422.

514 Nowlis JP. 1993. Mate-and oviposition-influenced host preferences in the coral-feeding 515 snail Cyphoma gibbosum. Ecology:1959-1969.

516 Palumbi SR. 1996. Nucleic acids II: the polymerase chain reaction. Molecular systematics $2: 205-247$.

518 Pfennig DW., Wund MA., Snell-Rood EC., Cruickshank T., Schlichting CD., Moczek AP. 2010. Phenotypic plasticity's impacts on diversification and speciation. Trends in Ecology \& Evolution 25:459-467. DOI: 10.1016/j.tree.2010.05.006. 
521 Randall JE. 2005. A review of mimicry in marine fishes. ZOOLOGICAL STUDIES-TAIPEI-

522 44:299.

523 Reijnen BT. 2015. Molecular data for Crenavolva species (Gastropoda, Ovulidae) reveals the 524 synonymy of C. chiapponii. ZooKeys: 15.

525 Reijnen BT., Hoeksema BW., Gittenberger E. 2010. Host specificity and phylogenetic 526 relationships among Atlantic Ovulidae (Mollusca: Gastropoda). Contributions to Zoology 79:69-78.

528 Rosenberg G. 1992. An introduction to the Ovulidae (Gastropoda: Cypraeacea). American $529 \quad$ Conchologist 20:4-7.

530 Sadler TD., Romine WL., Stuart PE., Merle-Johnson D. 2013. Game-Based Curricula in Biology Classes: Differential Effects Among Varying Academic Levels. Journal of Research in Science Teaching 50:479-499.

533 Sánchez JA., Gómez CE., Escobar D., Dueñas LF. 2012. Diversidad, abundancia, y amenazas 534 de los octocorales de isla Malpelo, Pacífico Oriental Tropical, Colombia. Revista de

535 Investigaciones Marinas \& Costeras 41.

536 Sánchez JA. 2013. Remarkable specialization in Eastern Pacific sea fan ectoparasites

537 (Neosimnia). Coral Reefs 32:891-891. DOI: 10.1007/s00338-013-1049-6.

538 Sánchez JA., N. E. Ardila., J. Andrade., L. F. Dueñas., R. Navas., D. Ballesteros. 2014. Octocoral 539 densities and mortalities in Gorgona Island, Colombia, Tropical Eastern Pacific. 540 Revista de Biología Tropical 62:209-219.

541 Sánchez JA., Ballesteros D. 2014. The invasive snowflake coral (Carijoa riisei) in the 542 Tropical Eastern Pacific, Colombia. Revista de Biología Tropical 62:197-207. 
543 Schiaparelli S., Barucca M., Olmo E., Boyer M., Canapa A. 2005. Phylogenetic relationships

544 within Ovulidae (Gastropoda: Cypraeoidea) based on molecular data from the $16 \mathrm{~S}$

545 rRNA gene. Marine Biology 147:411-420.

546 Stamatakis A. 2015. The RAxML v8. 2. X Manual. Structure.

547 Starrett A. 1993. Adaptive resemblance: a unifying concept for mimicry and crypsis.

548 Biological Journal of the Linnean Society 48:299-317.

549 Stevens M., Merilaita S. 2009. Animal camouflage: current issues and new perspectives.

$550 \quad$ Philosophical Transactions of the Royal Society B: Biological Sciences 364:423-427.

551 Stoddard MC. 2012. Mimicry and masquerade from the avian visual perspective. Current $552 \quad$ Zoology 58:630-648.

553 Teaching and Student Services. 2008. Coral Reefs: Science and COnservation.

554 Van't Hof AE., Nguyen P., Dalíková M., Edmonds N., Marec F., Saccheri IJ. 2013. Linkage map

555 of the peppered moth, Biston betularia (Lepidoptera, Geometridae): a model of

556 industrial melanism. Heredity 110:283-295.

557 Vargas S., Guzman HM., Breedy O. 2008. Distribution patterns of the genus Pacifigorgia 558

559 (Octocorallia: Gorgoniidae): track compatibility analysis and parsimony analysis of

\section{0}

561

Vermeij GJ. 2012. Crucibles of creativity: the geographic origins of tropical molluscan endemicity. Journal of biogeography 35:241-247.

562 West-Eberhard MJ. 2003. Developmental plasticity and evolution. Oxford University Press.

563 Yates TB., Marek EA. 2014. Teachers teaching misconceptions: a study of factors contributing to high school biology students' acquisition of biological evolutionrelated misconceptions. Evolution: Education and Outreach 7:7. 
